\title{
Acute renal failure following copper sulphate intoxication
}

\author{
K. S. Chugh \\ M.D., M.A.M.S., F.I.C.A. \\ B. K. Sharma \\ M.D., M.A.M.S. \\ P. C. Singhal \\ K. C. DAS \\ M.D., D.M. \\ D.Phil., M.A.M.S. \\ B. N. DATTA
M.D., M.A.M.S. \\ Divisions of Nephrology, Haematology and Pathology, \\ Postgraduate Institute of Medical Education and Research, Chandigarh, India
}

\begin{abstract}
Summary
Eleven out of a series of twenty-nine patients (37.9\%) with acute copper sulphate poisoning developed acute renal failure. Intravascular haemolysis appeared to be the chief factor responsible for renal lesions in these patients. Histological lesions observed in the kidney varied from those of mild shock to well established acute tubular necrosis. In one case, granulomatous lesions were seen in response to tubulorrhexis. Renal failure was the chief indication for dialysis in ten patients, whereas one patient was dialysed primarily for removal of copper. Notwithstanding the adequate control of uraemia by dialysis, only six of the eleven patients recovered. Septicaemia was responsible for death in three, hepatic failure in one and methaemoglobinaemia in another. It is postulated that release of copper from haemolysed red cells during acute haemolytic episodes may initiate, or contribute to, the development of renal damage.
\end{abstract}

\section{Introduction}

Ingestion of copper sulphate is a common mode of poisoning in India (Chuttani et al., 1965; Wahal et al., 1963), mostly for suicidal purposes, although accidental poisoning has been reported from children (Ghosh and Agarwal, 1962). The clinical course of the copper sulphate-intoxicated patient is often complex. The symptoms following mild intoxication generally comprise nausea, vomiting, diarrhoea and ptyalism. In severe cases haematemesis, melaena, intravascular haemolysis, jaundice, haemoglobinuria, oliguria, acute hepatic necrosis, hypotension, coma and death have been reported (Chuttani et al., 1965). Acute pancreatitis, myoglobinuria (Klein, Metz and Price, 1972) and methaemoglobinaemia (Chugh, Singhal and Sharma, 1975) have also been observed

Reprint requests: Dr K. S. Chugh, Professor and Head, Division of Nephrology, Postgraduate Institute of Medical Education and Research, Chandigarh, India. in some patients. There is paucity of published literature on the precise type of renal lesions seen in acute copper sulphate poisoning (Sanghvi et al., 1957). The present report is based on eleven patients with acute copper sulphate poisoning aged between 18 and 35 years who presented primarily with acute renal failure, and highlights the types of renal lesions seen in these patients, and their pathogenesis.

\section{Patients and methods}

Of twenty-nine patients with acute copper sul phate poisoning admitted to the Postgraduate Institute of Medical Education and Research, Chandigarh in North India, during the years 1964 to 1974 , eleven $(37.9 \%)$ presented with acute renal failure. One (case 11) was admitted immediately after ingestion of the chemical and the remainder were admitted between the third and eighth days. Copper levels in the blood, urine and dialysis fluid were estimated by the technique described by Rice (1960). Haematological investigations included estimation of haemoglobin, haematocrit, total and differential leucocyte count, reticulocyte count, plasma free haemoglobin and peripheral smear examination for red cell morphology by standard techniques. Screening for erythrocyte glucose 6phosphate dehydrogenase was carried out by the methaemoglobin reduction test. Biochemical investigations comprised estimation of blood urea, creatinine, sodium, potassium, chloride, bilirubin and serum transaminases.

Renal histology was available in eight of these patients, being undertaken by percutaneous needle biopsy in six cases and being studied on the postmortem specimens in two others.

\section{Observations}

The exact amount of copper sulphate ingested could not be determined for each patient but, based 
TABLE 1. Showing clinical data of eleven patients with acute renal failure

\begin{tabular}{|c|c|c|c|c|c|c|}
\hline $\begin{array}{l}\text { Case } \\
\text { no. }\end{array}$ & $\begin{array}{l}\text { Age } \\
\text { (years) } \\
\text { and } \\
\text { sex }\end{array}$ & Symptoms and signs & $\begin{array}{l}\text { Day of } \\
\text { referral }\end{array}$ & $\begin{array}{l}\text { Total dura- } \\
\text { tion of } \\
\text { oliguria/ } \\
\text { anuria (days) }\end{array}$ & Treatment & Result \\
\hline 1 & $20 \mathrm{M}$ & $\begin{array}{l}\text { Nausea, vomiting, diarrhoea, pain abdomen, jaundice, } \\
\text { melaena, dark urine, oliguria. }\end{array}$ & 3 & 3 & HD-1 & Survived \\
\hline 2 & $35 \mathrm{M}$ & $\begin{array}{l}\text { Nausea, vomiting, pallor, jaundice, haematemesis, } \\
\text { haematuria, oliguria, hypotension, hepatomegaly, } \\
\text { bronchopneumonia. }\end{array}$ & 4 & 8 & PD-3 & Died \\
\hline 3 & $19 \mathrm{M}$ & $\begin{array}{l}\text { Nausea, vomiting, burning in epigastrium, haematemesis, } \\
\text { pallor, fever, dark urine, oliguria. }\end{array}$ & 3 & 15 & HD-5 & Survived \\
\hline 4 & $22 \mathrm{M}$ & $\begin{array}{l}\text { Nausea, vomiting, melaena, pallor, jaundice, haematuria, } \\
\text { delirium, oliguria, bronchopneumonia. }\end{array}$ & 6 & 8 & HD-3 & Died \\
\hline 5 & $18 \mathrm{M}$ & $\begin{array}{l}\text { Nausea, vomiting, melaena, pallor, dark urine, delirium, } \\
\text { oliguria, bronchopneumonia. }\end{array}$ & 5 & 20 & HD-5 & Died \\
\hline 6 & $22 \mathrm{M}$ & $\begin{array}{l}\text { Nausea, vomiting, diarrhoea, haematemesis, pallor, jaundice, } \\
\text { melaena, anuria. }\end{array}$ & 5 & 17 & HD-5 & Survived \\
\hline 7 & $28 \mathrm{M}$ & $\begin{array}{l}\text { Nausea, vomiting, diarrhoea, melaena, pallor, dark urine, } \\
\text { jaundice, oliguria. }\end{array}$ & 3 & 11 & HD-3 & Survived \\
\hline 8 & $21 \mathrm{~F}$ & $\begin{array}{l}\text { Nausea, vomiting, pain epigastrium, melaena, pallor, } \\
\text { jaundice, oliguria. }\end{array}$ & 4 & 7 & HD-2 & Survived \\
\hline 9 & $21 \mathrm{M}$ & $\begin{array}{l}\text { Nausea, vomiting, haematemesis, diarrhoea, pain abdomen, } \\
\text { pallor, jaundice, dark urine, tender hepatomegaly. }\end{array}$ & 5 & 12 & HD-3 & Survived \\
\hline 10 & $22 \mathrm{M}$ & $\begin{array}{l}\text { Nausea, vomiting, pain epigastrium, haematemesis, dark red } \\
\text { urine, delirium, hypotension, coma, oliguria, tender } \\
\text { hepatomegaly. }\end{array}$ & 8 & No oliguria & HD-2 & Died \\
\hline 11 & $27 \mathrm{M}$ & Nausea, vomiting, diarrhoea, deep cyanosis, air hunger, coma. & $2 \mathrm{hr}$ & $16 \mathrm{hr}$ & PD-1 & Died \\
\hline
\end{tabular}

HD, Haemodialysis; PD, peritoneal dialysis.

Total duration calculated from onset of oliguria or anuria to the onset of diuretic phase or death.

TABLE 2. Laboratory data of eleven patients with acute renal failure

\begin{tabular}{|c|c|c|c|c|c|c|c|c|c|c|}
\hline Case no. & $\begin{array}{l}\text { Haemo- } \\
\text { globin } \\
(\mathrm{g} / 100 \mathrm{ml})\end{array}$ & $\begin{array}{c}\text { PCV } \\
(/ 100 \mathrm{ml})\end{array}$ & $\begin{array}{l}\text { Reticu- } \\
\text { locytes } \\
(/ 100 \mathrm{ml})\end{array}$ & $\begin{array}{l}\text { Plasma } \\
\text { haemo- } \\
\text { globin } \\
(\mathrm{mg} \%)\end{array}$ & $\begin{array}{l}\text { Haemo- } \\
\text { globin- } \\
\text { uria }\end{array}$ & $\begin{array}{c}\text { Serum } \\
\text { bilirubin } \\
(\mathrm{mg} / \\
100 \mathrm{ml})\end{array}$ & $\begin{array}{c}\text { Blood } \\
\text { urea at } \\
\text { first } \\
\text { dialysis } \\
(\mathrm{mg} / \\
100 \mathrm{ml})\end{array}$ & $\begin{array}{l}\text { Serum } \\
\text { creatinine } \\
\text { at first } \\
\text { dialysis } \\
(\mathrm{mg} / \\
100 \mathrm{ml})\end{array}$ & $\begin{array}{l}\text { Serum } \\
\text { potassium } \\
(\mathrm{mEq} / 1)\end{array}$ & $\begin{array}{c}\text { Serum } \\
\text { copper } \\
(\mu \mathrm{g} / \\
100 \mathrm{ml})\end{array}$ \\
\hline 1 & 8 & 30 & $4 \cdot 5$ & 45 & + & $4 \cdot 4$ & 107 & $5 \cdot 2$ & $5 \cdot 1$ & 260 \\
\hline 2 & $5 \cdot 4$ & 16 & $25 \cdot 6$ & 148 & + & 5 & 220 & $9 \cdot 8$ & $6 \cdot 5$ & 115 \\
\hline 3 & 5 & 18 & $8 \cdot 8$ & 31 & + & $1 \cdot 5$ & 83 & $4 \cdot 1$ & $6 \cdot 2$ & 206 \\
\hline 4 & 4 & 14 & $7 \cdot 5$ & 25 & + & 2 & 187 & $7 \cdot 8$ & $5 \cdot 9$ & 176 \\
\hline 5 & 4 & 14 & $4 \cdot 2$ & 21 & -4 & $1 \cdot 8$ & 198 & $8 \cdot 1$ & $4 \cdot 8$ & 156 \\
\hline 6 & $3 \cdot 5$ & 9 & $6 \cdot \overline{5}$ & 48 & + & 5 & 300 & $14 \cdot 4$ & $7 \cdot 2$ & 120 \\
\hline 7 & $7 \cdot 2$ & 25 & $5 \cdot 2$ & 35 & + & $3 \cdot 2$ & 242 & $10 \cdot 5$ & $5 \cdot 0$ & 183 \\
\hline 8 & 7 & 24 & $8 \cdot 5$ & 22 & + & $14 \cdot 5$ & 160 & $6 \cdot 2$ & $6 \cdot 8$ & 390 \\
\hline 9 & 3 & 13 & $14 \cdot 6$ & 32 & + & $2 \cdot 5$ & 441 & $14 \cdot 5$ & $6 \cdot 5$ & 129 \\
\hline 10 & 2 & 7 & 25 & 207 & + & $3 \cdot 5$ & 330 & $13 \cdot 5$ & $6 \cdot 0$ & 244 \\
\hline 11 & 9 & 36 & 6 & 2500 & - & $1 \cdot 9$ & 90 & $2 \cdot 5$ & $5 \cdot 2$ & $8267^{*}$ \\
\hline Mean & $5 \cdot 28$ & $18 \cdot 7$ & 10.6 & $283 \cdot 1$ & Positive & $4 \cdot 12$ & $214 \cdot 5$ & $8 \cdot 8$ & $5 \cdot 9$ & $197 \cdot 9$ \\
\hline
\end{tabular}

* Figure not included for calculating the mean.

on all sources of information, the individual amounts seemed to vary from 1 to $50 \mathrm{gm}$. The presenting features and clinical course of the eleven patients who developed renal failure have been charted in Table 1. The immediate symptoms following ingestion of the chemical included nausea and vomiting in all of the patients $(100 \%)$ and a severe burning sensation, or pain, in the epigastrium was experienced by five of them $(45 \cdot 4 \%)$. Five patients (cases $1,6,7$, 9, 11) developed diarrhoea. Evidence of gastrointestinal bleeding in the form of haematemesis or melaena was present in all except case 11. Ten patients $(90.9 \%)$ were oliguric or anuric but one patient continued to pass an adequate amount of urine. In nine cases the colour of the urine had become 'reddish' or 'darkish brown'. Physical 
TABLE 3. Comparison of clinical and laboratory data of eleven patients with, and eighteen patients without, renal failure

\begin{tabular}{|c|c|c|c|c|}
\hline \multirow[b]{2}{*}{ Clinical and laboratory data } & \multicolumn{2}{|c|}{$\begin{array}{l}\text { Patients with renal failure } \\
\text { (of eleven) }\end{array}$} & \multicolumn{2}{|c|}{$\begin{array}{l}\text { Patients without renal failure } \\
\text { (of eighteen) }\end{array}$} \\
\hline & No. & $\%$ & No. & $\%$ \\
\hline Gastrointestinal symptoms & 11 & 100 & 18 & 10 \\
\hline Hypotension & 2 & 18 & 3 & 17 \\
\hline $\begin{array}{l}\text { Intravascular haemolysis } \\
\text { (i) Raised plasma haemoglobin } \\
\text { (ii) Haemoglobinuria } \\
\text { (iii) Abnormal red cell morphology }\end{array}$ & $\begin{array}{l}11 \\
10 \\
11\end{array}$ & $\begin{array}{r}100 \\
91 \\
100\end{array}$ & $\begin{array}{l}6 \\
5 \\
6\end{array}$ & $\begin{array}{l}33 \cdot 3 \\
28 \\
33 \cdot 3\end{array}$ \\
\hline $\begin{array}{l}\text { Acute hepatic necrosis } \\
\text { Raised serum transaminases }\end{array}$ & 3 & 27 & 9 & 50 \\
\hline
\end{tabular}

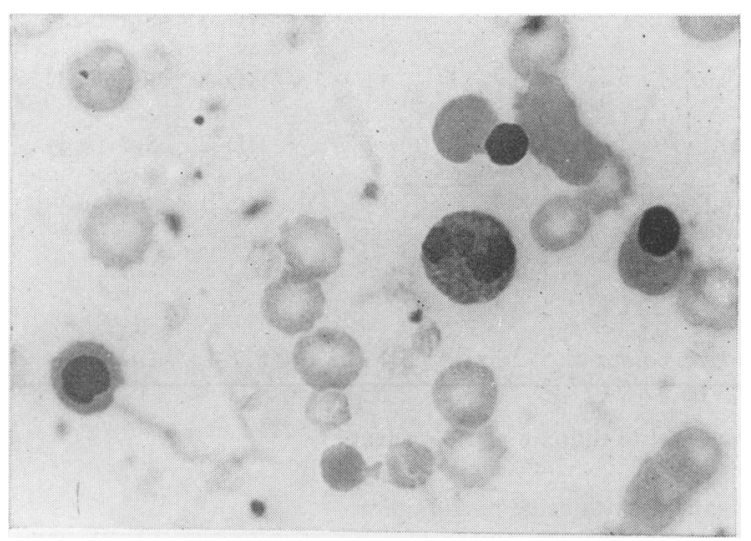

Fig. 1. Illustration of contracted, fragmented and crenated red cells seen in peripheral blood smear of a case of copper sulphate poisoning. The findings suggest acute intravascular haemolysis.

findings revealed severe pallor in ten patients $(90.9 \%)$ and jaundice in eight $(72 \cdot 7 \%)$. Three patients (cases $4,5,10)$ were delirious and two (cases 10,11 ) were comatose. Hypotension, because of lack of adequate replacement of fluids and electrolytes, was present in two patients (cases 2, 10). One patient (case 11) became deeply cyanosed $5 \mathrm{hr}$ after ingestion of the chemical. Tender hepatomegaly was present in three patients (cases 2, 9, 10).

Laboratory data of eleven patients who had developed acute renal failure are charted in Table 2. Peak blood urea levels before application of dialysis therapy varied from 83 to $441 \mathrm{mg} / 100 \mathrm{ml}$ (mean $214.4 \mathrm{mg} / 100 \mathrm{ml}$ ) and serum creatinine between 2.5 and $14.5 \mathrm{mg} / 100 \mathrm{ml}$ (mean $8.78 \mathrm{mg} / 100 \mathrm{ml}$ ). Evidence of acute intravascular haemolysis in the form of low haematocrit, presence of a significant quantity of plasma haemoglobin, haemoglobinuria, increased serum bilirubin and reticulocytosis, either singly or in combination, was noted in all the eleven patients. Plasma haemoglobin levels ranged from 21 to 2500 $\mathrm{mg} / 100 \mathrm{ml}$ (mean $283 \mathrm{mg} / 100 \mathrm{ml}$ ) and reticulocyte counts varied from 4.2 to $25 \%$ (mean $10.6 \%$ ). Examination of the peripheral blood smear showed contracted, crenated and fragmented red cells (Fig. 1). In some smears, erythrocyte ghosts and spherocytes could be seen.

Serum copper levels varied between 115 and 390 $\mu \mathrm{g} / 100 \mathrm{ml}$ (mean $197.9 \mu \mathrm{g} / 100 \mathrm{ml}$ ) and were higher than normal in eight patients (i.e. $>115 \mu \mathrm{g} / 100 \mathrm{ml}$ ). In one patient (case 11), because of profuse haemolysis, serum copper estimation was not possible and the whole blood copper level was found to be 8267 $\mu \mathrm{g} / 100 \mathrm{ml}$ and, in this patient, $36 \%$ of the haemoglobin was in the form of methaemoglobin.

The main clinical and laboratory data of eleven patients with renal failure and eighteen patients without renal failure are compared in Table 3. A difference in the incidence of haemolysis in the two groups is obvious, being present in all the eleven patients of the renal failure group and in only six patients $(33.3 \%)$ of the non-renal failure group. No significant difference was seen between the frequency of gastro-intestinal manifestations and hypotension, both of which could have influenced the development of renal lesions.

Initial therapy consisted of gastric lavage, parenteral administration of fluids, mannitol and diuretics in all the patients. One patient (case 11) was started on peritoneal dialysis soon after admission with the sole aim of removing the copper. The detailed findings of this patient have been published elsewhere (Chugh, Singhal and Sharma, 1975). Ten patients who were admitted to hospital with established renal failure were treated with the Kiil dialyser (Table 1). Because of the rapid daily rise of urea (more than $100 \mathrm{mg} / 100 \mathrm{ml}$ in cases $2,6,9$ and 10) and the frequent tendency to develop hyperkalaemia (cases 2, 3, 4, 6, 8, 9 and 10), these patients required repetition of dialysis every 48-72 hr. Intermittent dialysis therapy was continued in each patient until either the diuretic phase ensued, or the 


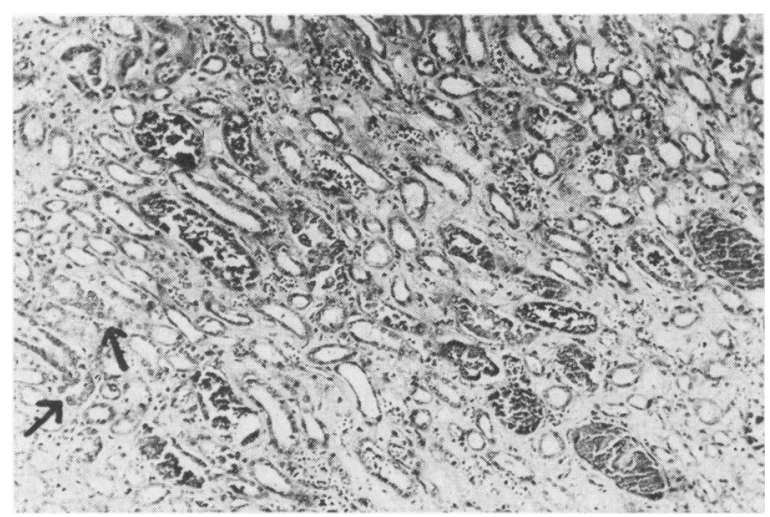

FIG. 2. Renal biopsy from case 2. Shown are lesions of acute tubular necrosis. Tubules show loss of epithelial lining and contain casts. The arrows point to tubules showing regenerating epithelium. Interstitial tissue shows oedema and scattered inflammatory cells (H \& E $\times 90$ ).

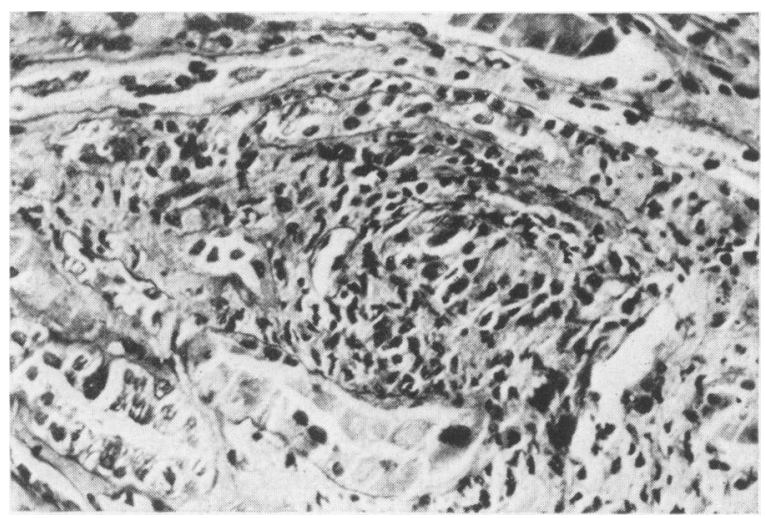

Fig. 3. Granuloma formation in response to ruptured tubules in case 7 (PAS $\times 400)$.

patient died. The number of dialyses performed varied from one to five.

Six patients recovered and five died (cases 2, 4, 5, 10 and 11), death being due to fulminating septicaemia and bronchopneumonia in three patients (cases 2, 4 and 5), hepato-renal failure in one (case 10) and methaemoglobinaemia giving rise to severe hypoxia in another (case 11).

Histological lesions in the kidney could be examined in eight patients, the features of acute tubular necrosis being seen in seven of them. The tubules showed loss of epithelial lining and contained haemoglobin casts (Fig. 2). Still others showed proliferation of cells indicating regeneration, presence of interstitial oedema and scattered inflammatory cells. In one case (no. 7), the inflammatory reaction had led to granuloma formation in response

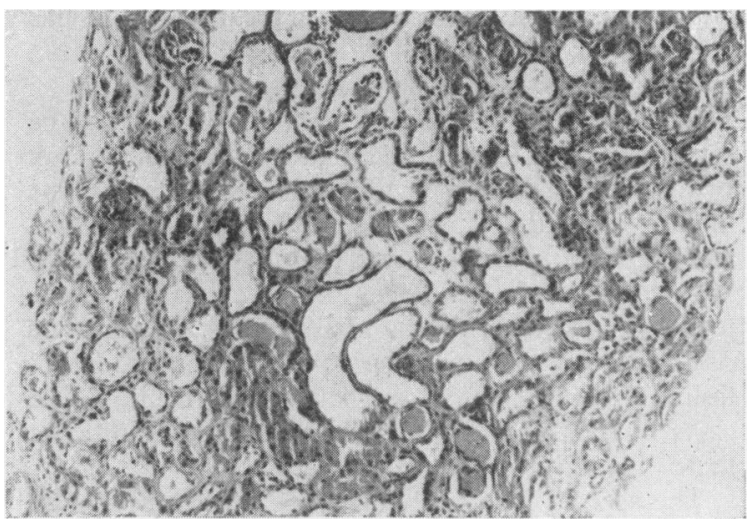

FIG. 4. Tubules showing dilatation and flattened epithelium during recovery phase $(H \& E \times 90)$.

to ruptured tubules (Fig. 3). During the recovery phase, the striking feature was the uniformly dilated tubules with flattened epithelial lining (Fig. 4). Significant morphological changes seen in the other viscera of two patients (cases 10,11 ) coming to postmortem were superficial and deep ulcers in the stomach and small intestine, and acute liver cell necrosis with bile thrombi.

\section{Discussion}

The striking feature of the eleven copper-intoxicated patients who developed acute renal failure was the presence of acute intravascular haemolysis as shown by fall in the haemoglobin and haematocrit levels, increased plasma haemoglobin, reticulocytosis, haemoglobinuria, raised bilirubin, and presence of crenated, fragmented and contracted red cells in the peripheral blood smear. Copper is known to produce haemolysis by damaging the red cell membrane, denaturation of haemoglobin, Heinz body formation (Salvati, Ambrogioni and Tentoni, 1969) or by inhibiting cellular metabolism (Oski, 1970). Even in very low concentrations it may interfere with activity of various cellular enzymes such as adenosine triphosphate (Bowler and Duncan, 1970), erythrocyte glucose 6-phosphate dehydrogenase (G 6-PD) (Fairbanks, 1967), glutathione reductase and catalase (Metz, 1969). That copper sulphate accelerates the oxidation of reduced nicotine adenine dinucleotide phosphate (NADPH) has been shown by Fairbanks (1967). Two of the patients in the present study showed erythrocyte G 6-PD-deficiency (cases $10,11)$. Whether this was induced by copper, or whether these patients had a pre-existing G 6-PD deficiency could not be ascertained, since both of them died during the course of the acute illness. There appeared to be no correlation between the serum copper levels and production of intravascular 
haemolysis in these patients, a finding which has been previously observed by others (Chuttani et al., 1963; Ivanovich, Manzler and Drake, 1969).

Several patho-physiological mechanisms could be involved in the development of acute renal failure. From the observations made in the present study, the likelihood is that intravascular haemolysis played the major role in the copper-intoxicated patients. Whereas renal failure developed in eleven of seventeen patients $(64.7 \%)$ who showed haemolysis, none of the twelve without haemolysis developed renal failure. Intralumenal obstruction by haemoglobin casts further pointed to haemolysis as a significant factor leading to renal failure.

The second factor which would seem relevant to such patients is the direct toxic action of the metal on the kidney. In the literature, little information is available on the renal toxicity of copper following acute intoxication either in experimental animals or in humans. Most of the reported studies have focused attention on the toxic damage to the proximal tubular epithelium (Vogel, 1960) and the distribution and concentration of the metal in various viscera following chronic copper loading in animals (Lal and Sourkes, 1971) and on patients with Wilson's disease (Walshe, 1966). In these studies, the major site of deposition of copper has been the liver. Extrahepatic deposition of the metal does occur but only after the hepatic binding sites get saturated (Sternleib and Scheinberg, 1968). Todd (1969) observed that extrahepatic deposition of copper, particularly in the kidney and spleen, occurred only after the animal had undergone a haemolytic crisis. It is suspected that a similar event takes place during acute haemolytic episodes following acute copper intoxication. The copper released from the haemolysed red cells is deposited in the tubular epithelium of the kidney, thus initiating or contributing to the development of renal lesions of acute tubular necrosis. It is likely, therefore, that renal lesions in copper intoxicated patients are due to intravascular haemolysis per se, as well as to the direct renal toxicity of the metal triggered by the deposition of copper during haemolytic episodes. Severe vomiting, diarrhoea, lack of replacement of fluid and gastrointestinal bleeding which could also have contributed to renal failure, were significant only in two patients (cases 2, 10).

The exact mechanism of renal failure following acute intravascular haemolysis is so far not well understood. The presence of pigment casts in the tubules led Bywaters and Stead (1944) to believe that tubular obstruction was the major factor. Blackburn et al. (1954) suggested that the haem pigment had a direct toxic effect on the tubules. Whereas intravenous injection of haemoglobin failed to produce renal failure (Brandt, Frank and Lichtman, 1951), infusion of haemolysed whole blood produced marked vasoconstriction and renal failure (Conn et al., 1954, 1956). Free haemoglobin levels in the plasma of above $200 \mathrm{mg} / 100 \mathrm{ml}$ have been reported to be particularly toxic to the renal tubular cells (Yeh et al., 1964). In the presence of factors such as dehydration, hypotension and anoxia, which in themselves may not be significant, even smaller amounts of free haemoglobin may produce renal failure. All these factors are invariably present in cases of copper sulphate poisoning.

An important feature of the patients in this study was their frequent tendency to develop a hypercatabolic state. This was evident from the daily rise of blood urea of more than $100 \mathrm{mg} / 100 \mathrm{ml}$ in four patients and a tendency to develop hyperkalaemia in seven patients. In this respect these cases are comparable to post-traumatic renal failure and require more frequent dialyses. A hypercatabolic state in these patients is likely to have been due to massive tissue necrosis resulting from the direct corrosive action of copper on the gastrointestinal tract, as well as intravascular haemolysis.

That copper is a dialysable substance has been shown indirectly by two separate studies, Matter et al. (1969) and Klein et al. (1972) having reported acute copper intoxication during haemodialysis. The metal was shown to have reached the blood compartment from the plumbing of the dialysate delivery system via the dialysis membrane. A recent report by Agarwal et al. (1975), however, has doubted the role of haemodialysis in cases of copper sulphate poisoning. Direct evidence of its dialysability was obtained in the present study by recovering copper from the dialysate during peritoneal dialysis in one patient who was admitted within $2 \mathrm{hr}$ of ingesting copper sulphate (Chugh et al., 1975) and also in two experimental studies carried out in dogs. In the latter studies, copper was recovered in the outflow dialysate following haemodialysis carried out within $24 \mathrm{hr}$ of administration of a lethal dose of copper sulphate (Chugh, Sharma and Singhal, unpublished data). Further studies to elucidate the role of haemodialysis in the later period are in progress. The evidence so far available suggests that removal of copper by dialysis is certainly indicated in the early stages of poisoning when the metal is still present in the circulation as free copper.

\section{References}

Agarwal, B.N., Bray, S.H., Bercz, P., Plotzker, R. \& LABovitz, E. (1975) Ineffectiveness of haemodialysis in copper sulphate poisoning. Nephron, 15, 74.

Blackburn, C.R.B., Honsley, W.J., Grant, D.K. \& WRIGHT, F.B. (1954) Studies on intravascular haemolysis in man. The pathogenesis of the initial stages of acute renal failure. Journal of Clinical Investigation, 33, 825.

Bowler, K. \& Duncan, C.J. (1970) The effect of copper on membrane enzymes. Biochimica et biophysica acta, 196, 116. 
Brandt, J.L., Frank, N.R. \& Lichtman, H.C. (1951) Effects of haemoglobin solution on renal functions in man. Blood, 6, 1152.

Bywaters, E.G.L. \& Stead, J.K. (1944) Production of renal failure following injection of solution containing myohaemoglobin. Quarterly Journal of Experimental Physiology and Cognate Medical Sciences, 33, 53.

Chugh, K.S., Singhal, P.C. \& Sharma, B.K. (1975) Methemoglobinemia in acute copper sulphate poisoning. Annals of Internal Medicine, 82, 226.

Chuttani, H.K., Gupta, P.S., Gulati, S. \& Gupta, D.N. (1965) Acute copper sulphate poisoning. American Journal of Medicine, 39, 849.

ConN, H.L., JR, Wilds, L. \& Helwig, J. (1954) Study of renal circulation, tubular function and morphology and urinary volume and composition in dogs following mercury poisoning and transfusion of human blood. Journal of Clinical Investigation, 33, 732.

ConN, H.L., JR, Wood, J.C. \& Rose, J.C. (1956) Circulatory and renal effects following transfusion of human blood and its components to dogs. Circulation Research, 4, 18.

FaIrbanks, V.F. (1967) Copper sulphate-induced hemolytic anemia. Archives of Internal Medicine, 120, 428.

Ghosh, S. \& Agarwal, V.P. (1962) Accidental poisoning in childhood. Journal of the Indian Medical Association, 39, 635.

Ivanovitch, P., Manzler, A. \& Drake, R. (1969) Acute hemolysis following hemodialysis. Transactions of the American Society for Artificial Internal Organs, 15, 316.

Klein, W.J. JR, Metz, E.N. \& Price, A.R. (1972) Acute copper intoxication hazard of hemodialysis. Archives of Internal Medicine, 129, 578.

LAL, S. \& Sourkes, T.L. (1971) Deposition of copper in the rat tissues - the effect of dose and duration of administration of copper sulfate. Toxicology and Applied Pharmacology, 20, 269.
Matter, B.J., Pederson, J.G., Psimenos, G. \& Lindeman, R.D. (1969) Lethal copper intoxication in hemodialysis. Transactions of the American Society for Artificial Internal Organs, 15, 309.

Metz, E.N. (1969) Mechanism of hemolysis by excess copper (abstract). Clinical Research, 17, 32.

OsKi, F.A. (1970) 'Chickee, the copper.' Annals of Internal Medicine, 73, 485 .

RICE, E.W. (1960) Spectrophotometric determination of serum copper with oxalydihydrazide. Journal of Laboratory and Clinical Medicine, 55, 325.

Salvati, A.M., Ambrogioni, M.T. \& Tentoni, L. (1969) The autoxidation of haemoglobin. Effect of copper. Italian Journal of Biochemistry, 18, 1.

Sanghvi, L.M., Sharma, R., Misra, S.N. \& Samuel, K.C. (1957) Sulfhemoglobinemia and acute renal failure after copper sulfate poisoning. Archives of Pathology, 63, 172.

Sternleib, I. \& SCHEInberg, I.H. (1968) Prevention of Wilson's disease in asymptomatic patients. New England Journal of Medicine, 278, 352.

ToDD, J.R. (1969) Chronic copper toxicity of ruminants Proceedings of the Nutrition Society, 28, 189.

VoGEL, F.S. (1960) Nephrotoxic properties of copper under experimental conditions in mice: with special reference to pathogenesis of renal alterations in Wilson's disease. American Journal of Pathology, 36, 699.

Wahal, P.K., Lahiri, B., Mathur, K.S., Usha, K. \& Wahi, P.N. (1963) Acute copper sulphate poisoning. The Journal of the Association of Physicians of India, 11, 93.

WALSHE, J.M. (1966) Wilson's disease. A review. In: Biochemistry of Copper (Ed. by J. Peisach, P. Aisen and W. E. Blumberg), p. 475. Academic Press, New York.

Yeh, T.J., Brackney, E.L., Hall, D.P. \& Ellison, R.G (1964) Renal complication of open-heart surgery: predisposing factors, prevention and management. Journal of Thoracic and Cardiovascular Surgery, 47, 79. 